\title{
Assessment of the exposure of islanders to ash from the Soufriere Hills volcano, Montserrat, British West Indies
}

\author{
A Searl, A Nicholl, P J Baxter
}

Occup Environ Med 2002;59:523-531

See end of article for authors' affiliations

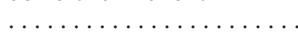

Correspondence to: Dr A Searl, Institute of Occupational Medicine, 8 Roxburgh Place,

Edinburgh EH8 9SU, UK: alison.sear@iomhq.org.uk

Accepted

13 February 2002

\begin{abstract}
Background and Aims: The Soufriere Hills volcano, Montserrat, has been erupting since July 1995 and volcanic ash has fallen on the island throughout most of the eruption. The ash contains substantial quantities of respirable particles and unusually large amounts (15-20\%) of the crystalline silica mineral, cristobalite. The purpose of the surveys described here, undertaken between December 1996 and April 2000, was to determine levels of personal exposure of islanders to volcanic ash and cristobalite in order to inform advice on the associated risks to health and the measures required to reduce exposure.

Methods: Surveys of personal exposure to respirable dust and cristobalite were undertaken using cyclone samplers. In addition, direct reading instruments (DUSTTRAK) were used to monitor ambient air concentrations of $\mathrm{PM}_{10}$ at fixed sites and also to provide information about exposures to airborne particles associated with selected activities.

Results: Environmental concentrations of airborne ash have been greatest in the areas where the most ash has been deposited and during dry weather. Individual exposure to airborne ash was related to occupation, with the highest exposures among gardeners, cleaners, roadworkers, and police at roadside checkpoints. During 1997 many of these individuals were exposed to concentrations of cristobalite that exceeded the ACGIH recommended occupational exposure limit. Since the population became confined to the north of the island in October 1997, even those in relatively dusty occupations have received exposures to cristobalite well below this limit.

Conclusions: Most of the 4500 people who have remained on island since the eruption began have not been exposed to sufficiently high concentrations of airborne dust for long enough to be at risk of developing silicosis. However, more than a dozen individuals continued to experience frequent high occupational exposures to volcanic ash, some of whom may have had sufficient exposure to crystalline silica to be at risk of developing mild silicosis. If volcanic activity were to deposit further ash over the occupied areas of the island during the coming years, the risks of silicosis will become more substantial.
\end{abstract}

$\mathrm{T}$ he Soufriere Hills volcano, Montserrat, began erupting on 19 July 1995, and during the course of the eruption a substantial amount of ash has been deposited, mainly on the southern part of the island downwind of the volcano (fig 1). Since August 1997 about 4500 of the original 12000 population have remained on the island. The capital, Plymouth, was evacuated in April 1996, although the port was kept open and people were allowed into Plymouth during safe periods to clear ash from their properties. Following a major eruption on 25 June 1997 when 19 people were killed in the exclusion zone, Cork Hill and all other areas south of the Belham River were evacuated and activities in Plymouth ceased. Continuing high levels of volcanic activity during the summer and autumn of 1997 led to the official evacuation of the Salem area in the central part of Montserrat in August 1997. This high level of activity continued until March 1998 when magma extrusion and dome growth ceased. Minor explosive activity and venting episodes leading to light ashfalls continued to occur into 1999, which started to tail off until in November magmatic activity unexpectedly resumed, leading to renewed dome growth. The eruption is marked by the growth of a lava dome in the old crater that periodically produces large ash emissions when it collapses or explodes. Exposure of the island's population to ash has occurred during ashfalls and more importantly as a result of the subsequent resuspension of ash particles by human activity and wind. The ash falls as aggregates of particles that readily disintegrate on disturbance to create a cloud of fine dust.

In September 1996, preliminary analysis of the ash showed unexpectedly high levels of crystalline silica ( 15-20 weight \%) and substantial quantities of particles small enough to be able to penetrate to the lung (13-20 weight \% of particles are smaller than $10 \mu \mathrm{m}) .{ }^{1}$ The silica is present as cristobalite. ${ }^{1}$ Exposure to crystalline silica can lead to silicosis, and the International Agency for Research on Cancer (IARC) has classified crystalline silica as a human carcinogen. ${ }^{2}$ Animal experiments have suggested that cristobalite has a greater potential to cause lung disease than the more common silica polymorph, quartz. ${ }^{3}$ The raised cristobalite concentration of the ash, the fineness of the ash particles, and their freshly fractured surfaces unaltered by the high temperature of the dome $\left(>800^{\circ} \mathrm{C}\right)$, all suggested that the ash was a respiratory hazard. In addition, freshly erupted ash contains water soluble sulphates, chlorides, and fluorides adsorbed on particle surfaces and has a surface acidity, that might add to the irritant effects of the ash on the airways. Given these concerns, surveys were undertaken to establish the levels of exposure of the islanders to the ash, the results of which are summarised here. In addition, an air quality monitoring network was established to provide daily information for islanders about particle concentrations in the ambient air.

Abbreviations: ACGIH, American Conference of Government Industrial Hygienists; BMRC, British Medical Research Council; DoH, Department of Health; HSE, Health and Safety Executive; IARC, International Agency for Research on Cancer; MEL, maximum exposure limit; MVO, Montserrat Volcano Observatory; TLV, threshold limit value 


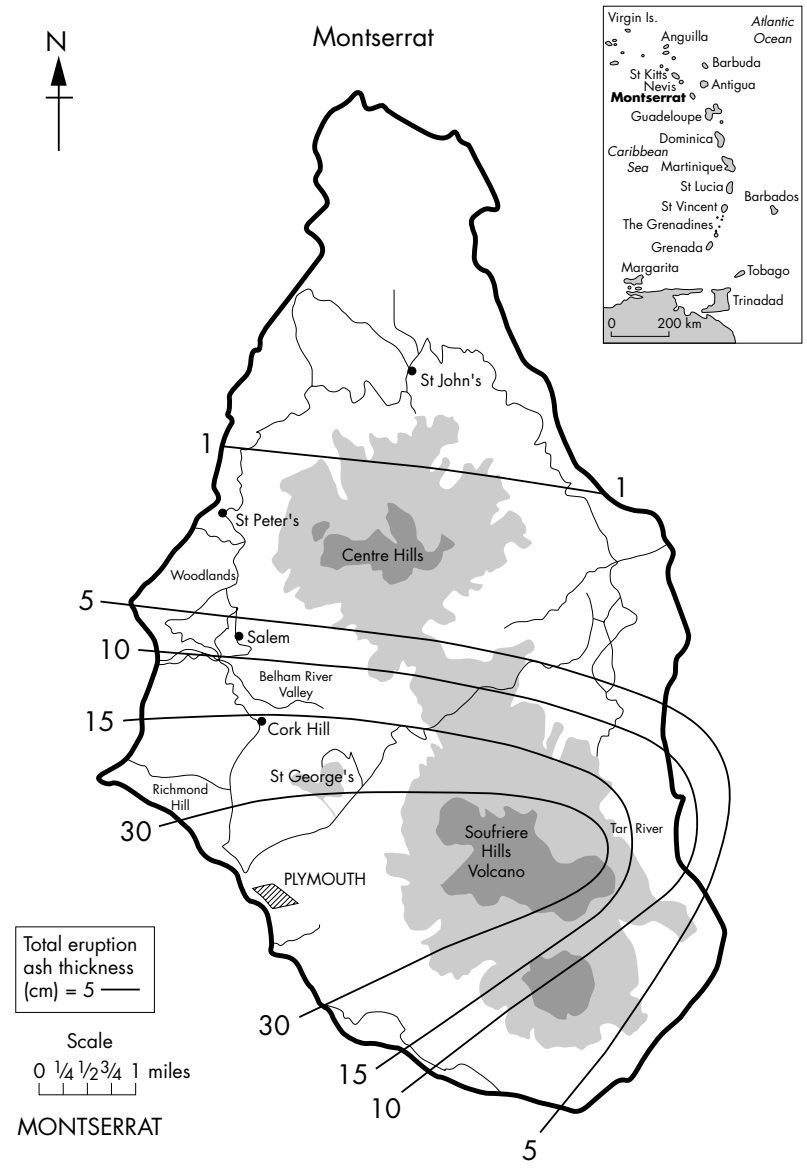

Figure 1 Map of Montserrat showing locations referred to in the text and thickness of ash deposited on different parts of the island.

The aims of the surveys were:

(1) To assess the concentrations of respirable dust and cristobalite to which islanders have been exposed during the course of the eruption

(2) To assess the risks to respiratory health that might be associated with the islanders' exposure to volcanic ash.

The island government advised the people on measures to minimise their exposure to the ash and made appropriate masks generally available.

\section{METHODS}

\section{Measurement of exposure}

The sampling strategy adopted was intended to provide representative information about the exposure of the general population on Montserrat and also to provide representative information about the exposure of the most highly exposed groups on the island. These included both those living in the areas most affected by the volcano and those in occupations that led to relatively high levels of exposure to the ash. We also undertook measurements of the exposure concentrations associated with a wide range of specific tasks and activities such as cleaning, ash clearing, gardening, manning a roadside checkpoint, outdoor play, and indoor office work. These measurements were used to improve our estimates of personal exposures to respirable ash and cristobalite, particularly where good full shift measurements of occupational exposure, or measurements of 24 hour exposure of the general population could not be readily obtained.

Three different sampling conventions have been used in the assessment of airborne dust concentrations on Montserrat. Concentrations of workplace dusts are usually determined for the respirable fraction, which represents those particles that can penetrate to the small airways in the deep lung. The UK Health and Safety Executive (HSE) adopted the ISO respirable sampling convention in 1997. The ISO respirable convention is expressed as a cumulative log normal function of total airborne dust with a median aerodynamic diameter of $4 \mu \mathrm{m}$ $\left(\mathrm{PM}_{4}\right){ }^{4}$ Prior to 1997 , the HSE had set limits with respect to the British Medical Research Council (BMRC) respirable convention that had had a slightly coarser median diameter $(5$ $\mu \mathrm{m})$. In order to maintain a similar level of control of workplace dust concentrations, the UK workplace limits for respirable substances were reduced by $20-25 \%$ in 1997 to reflect the change in sampling convention. The $\mathrm{PM}_{10}$ fraction is widely used for environmental monitoring. It is approximately equivalent to the ISO thoracic fraction and represents the particles that penetrate to the lung (median diameter is $10 \mu \mathrm{m}$ ). A large number of studies of urban populations have shown relations between concentrations of ambient $\mathrm{PM}_{10}$ and cardiorespiratory morbidity and mortality. ${ }^{4}$

The composition of volcanic ash collected from ash deposits on the island has been investigated using a variety of analytical techniques. ${ }^{1}$ Two main methods were used to assess concentrations of airborne dust on the island. Cyclone samplers were used to collect samples of respirable dust on filter following standard occupational hygiene methods, ${ }^{5}$ and these samples were analysed by $x$ ray diffraction to determine their cristobalite content. ${ }^{6}$ The samples made in 1996 and 1997 were collected in accordance with the BMRC respirable convention, but more recent samples were collected in accordance with the ISO respirable convention. For eight hour samples the limits of detection for respirable dust and cristobalite were $50 \mu \mathrm{g} / \mathrm{m}^{3}$ and $10 \mu \mathrm{g} / \mathrm{m}^{3}$ respectively, and for 24 hour samples, $18 \mu \mathrm{g} / \mathrm{m}^{3}$ and 3 $\mu \mathrm{g} / \mathrm{m}^{3}$ respectively. Both the gravimetric and $x$ ray diffraction analysis were performed in a UKAS accredited laboratory, and the results of replicate analysis of sample filters were within $10 \%$ of the original results. A continuous reading aerosol monitor, the DUSTTRAK, supplied by TSI, was used to measure concentrations of $\mathrm{PM}_{10}$ in real time. The DUSTTRAK is supplied with a certificate of calibration and the zero was checked at the beginning and end of each measurement period. Normally the zero drifted by less than $2 \mathrm{\mu g} / \mathrm{m}^{3}$ but drifts of up to $10 \mu \mathrm{g} / \mathrm{m}^{3}$ were associated with some of the highest measurements $(>1000$ $\mu \mathrm{g} / \mathrm{m}^{3}$ ). A limited comparison exercise was undertaken in old Towne in June 1997 to determine the relation between respirable dust as measured using the cyclones and $\mathrm{PM}_{10}$ as measured using the DUSTTRAK. Bulk samples of ash were also analysed for crystalline silica, including the $\mathrm{PM}_{10}$ fraction, by the British Geological Survey.

We performed detailed surveys of environmental concentrations of respirable airborne dust and cristobalite on Montserrat using cyclone samplers in September 1996 and June 1997. Some additional measurements were made by staff based at Montserrat Volcano Observatory (MVO) using cyclone samplers between the two main measurement campaigns in 1996 and 1997 and during the course of 1997. Further measurements of environmental concentrations of $\mathrm{PM}_{10}$ were made during June 1997 using a DUSTTRAK monitor. Additional information about typical dust levels was derived from informal interviews with islanders in June 1997 about how frequently ash fell and how long conditions remained noticeably dusty after each ash fall. Between September 1997 and November 1998, and again between May 1999 and August 1999, daily measurements of $\mathrm{PM}_{10}$ were made at various locations in the occupied part of the island using DUSTTRAK monitors. Information collected by MVO about the primary distribution of ash from the volcano and the weekly MVO reports describing levels of volcanic activity have provided additional information about the potential for individuals to be exposed to volcanic ash.

Our detailed surveys of personal exposures to respirable airborne dust and cristobalite on Montserrat were undertaken 
using cyclone samplers in September 1996 and June 1997 and again in April 2000. Personal samples were taken in the breathing zone of the sampled individuals. Several specific assessments of approximate personal exposures to $\mathrm{PM}_{10}$ were made for groups of islanders of particular interest during the course of 1998 using DUSTTRAK monitors held as close as possible to the breathing zone of individuals. This included surveys of the exposure of schoolchildren, roadworkers, MVO staff, and people engaged in ash clearing operations. These approximate personal exposure concentrations were considerably higher than background concentrations of $\mathrm{PM}_{10}$ at the same location, but are likely to have underestimated peak personal exposures for the dustiest occupations. This was because of the difficulty of holding the DUSTTRAK very close to the head of individuals engaged in active physical work.

\section{Assessment of average levels of exposure over the course of the eruption}

Average (mean) personal exposures for different groups of islanders were estimated from the measurement data. The islanders were grouped by place of residence as of mid 1996:

- Cork Hill: Cork Hill, Richmond Hill, St Georges

- Salem: Salem, Frith, Old Towne, Olveston

- North: Woodlands and all areas further to the north of the island including St Peters, Brades, and St Johns.

Islanders who originally lived in Plymouth, St Patricks, and other villages in the south of the island and villages on the east were all relocated early on during the eruption (April 1996). They would not have been exposed to substantial amounts of ash previously.

Islanders were also grouped by their potential exposure to ash associated with work or similar activities:

- Sedentary adults: largely the elderly and any others not working (paid or unpaid) or actively seeking employment

- Active adults: most adults, including all those with relatively low levels of exposure to dust in the workplace (for example, office workers, shop workers, health care, education)

- Adults in dusty occupations: adults with relatively high levels of dust exposure, including gardeners, police manning roadside checkpoints, handymen, roadworkers and any others employed in ash clearing operations, housekeepers (during the height of the ash fall activity), people working in Plymouth during the early part of 1997

- Children.

The exposure estimations for each group were done by assessing the typical proportion of each week spent on different categories of activities:

- Inactive: for example, sleeping, watching TV

- Active indoors: for example, office work, health care, retail, housework, school

- Outdoor play: for example, basketball, cricket

- Working in dusty occupations.

The estimated duration of each activity was based on interview information from a range of individuals, including those we sampled and our own observations of lifestyle.

Days were classified into four categories of dustiness based on criteria issued specifically to the island by the Department of Health for England (DoH) for $\mathrm{PM}_{10}$ : alert level $\left(>300 \mu \mathrm{g} / \mathrm{m}^{3}\right)$, very high $\left(101-300 \mu \mathrm{g} / \mathrm{m}^{3}\right)$, raised $\left(50-100 \mu \mathrm{g} / \mathrm{m}^{3}\right)$, and low $\left(<50 \mu \mathrm{g} / \mathrm{m}^{3}\right)$. The proportion of days in each dustiness category in each year or part year considered was based on $\mathrm{PM}_{10}$ measurement data where available. Otherwise the proportion was estimated from accounts of the level of volcanic activity, interview information from a range of individuals on the island, and extrapolation from measurement data. Rainfall information collected by the Montserrat Forestry Development
Office for 1999-2000 was also used in the assessment of the probable portion of days of differing dustiness for periods for which no monitoring data was available.

A typical level of personal exposure was assigned to each category of activity on days of differing dustiness based on measurement data. The mean level of personal exposure for each population group associated with days of differing dustiness was calculated as a time weighted mean based on the estimated weekly activity of each population group. The estimated number of hours spent on each category of activity each day (as averaged over a whole week) was multiplied by the estimated personal exposure concentration associated with that activity for a given dust category. These cumulative personal exposure concentrations for each individual category were summed and then divided by the number of hours in a day to give the mean exposure for each population group on days of differing dustiness.

The overall mean level of exposure over a given time period for each population group was determined by multiplying the mean exposure associated with each level of dustiness by the estimated proportion of days on which that level dustiness prevailed. These quantities were then summed to give an estimated overall mean exposure.

\section{Relevant occupational and environmental exposure standards}

Table 1 shows some occupational and environmental exposure standards and limits for respirable dust and silica. Occupational exposure limits assume that individuals are only exposed at work (that is, 40 hours a week for 46 weeks a year for 40 years). In any year that an individual is employed they would spend about $20 \%$ of their time at work. Environmental exposure to a substance is therefore equivalent to an occupational exposure of five times the environmental concentration. Workplace limits to control dust exposure are intended to reduce the risk of chronic respiratory conditions such as pneumoconiosis, chronic bronchitis, emphysema, and silicosis. They are also set to protect the health of initially healthy adults of working age. The HSE limits are enforced by law within the UK, whereas the American Conference of Government Industrial Hygienists (ACGIH) threshold limit value (TLV) has a purely advisory status. The maximum exposure limit (MEL) for silica set by the HSE is health based, but also takes account of social and economic factors. In contrast, the TLV is entirely health based and set without regard of practicability. The UK air quality standard for $\mathrm{PM}_{10}$ is also entirely health based and was set to protect susceptible individuals in the general population from acute respiratory and cardiac illness.

In order that the population of Montserrat could be kept adequately informed about airborne dust concentrations, the

\begin{tabular}{|c|c|c|c|}
\hline & Workplace* & Workplace/5 & Environmenta \\
\hline $\begin{array}{l}\text { Respirable dust } \\
\text { HSE } \dagger \\
\text { EPAQS } \ddagger\left(P_{10}\right)\end{array}$ & $4000 \mu \mathrm{g} / \mathrm{m}^{3}$ & $800 \mu \mathrm{g} / \mathrm{m}^{3}$ & $50 \mu \mathrm{g} / \mathrm{m}^{3}$ \\
\hline $\begin{array}{l}\text { Crystalline silica } \\
\text { HSE } \dagger \\
\text { ACGIH cristobalite } \\
\text { ACGIH quartz }\end{array}$ & $\begin{array}{l}300 \mu \mathrm{g} / \mathrm{m}^{3} \\
50 \mu \mathrm{g} / \mathrm{m}^{3} \\
100 \mu \mathrm{g} / \mathrm{m}^{3}\end{array}$ & $\begin{array}{l}80 \mu \mathrm{g} / \mathrm{m}^{3} \\
10 \mu \mathrm{g} / \mathrm{m}^{3}\end{array}$ & $\begin{array}{l}80 \mu \mathrm{gg} / \mathrm{m}^{3} \\
10 \mathrm{\mu g} / \mathrm{m}^{3}\end{array}$ \\
\hline
\end{tabular}

*These standards are time weighted averages over 8 hours, and assume a 40 hour working week.

TThese limits apply to the ISO convention for respirable dust; the limits that applied using the BMRC convention were $5000 \mathrm{\mu g} / \mathrm{m}^{3}$ for respirable dust and $400 \mu \mathrm{g} / \mathrm{m}^{3}$ for silica.

‡Department for the Environment, Transport and the Regions Expert Panel on Air Quality Standards. 
Table 2 Air quality alert levels (one hour averages) for $\mathrm{PM}_{10}$ on Montserrat

\begin{tabular}{|c|c|c|}
\hline $\begin{array}{l}\mathrm{PM}_{10} \\
\left(\mu \mathrm{g} / \mathrm{m}^{3}\right)\end{array}$ & Description & Action \\
\hline$<50$ & Ash levels low & None \\
\hline $51-100$ & Ash levels raised & $\begin{array}{l}\text { Those who have experienced effects on health during past dusty } \\
\text { episodes, especially asthmatics, should ensure they have masks available }\end{array}$ \\
\hline $101-300$ & Ash levels very high & Masks should be worn \\
\hline$>300$ & Ash levels alert & Masks should be worn and efforts made to reduce exposure \\
\hline
\end{tabular}

Table 3 Environmental concentrations of respirable dust and cristobalite $\left(\mu \mathrm{g} / \mathrm{m}^{3}\right)$

\begin{tabular}{|c|c|c|c|c|}
\hline & Plymouth & Cork Hill & Salem & North \\
\hline $\begin{array}{l}\text { September } 1996 \\
\text { Respirable dust } \\
\text { Cristobalite } \\
\text { No. samples }\end{array}$ & $\begin{array}{l}153(30-310) \\
11(<10-19) \\
12\end{array}$ & $\begin{array}{l}183(10-360) \\
11(<10-31) \\
12\end{array}$ & $\begin{array}{l}76(20-270) \\
6(<10-19) \\
7\end{array}$ & \\
\hline $\begin{array}{l}\text { October } 1996 \text { to } \\
\text { Respirable dust } \\
\text { Cristobalite } \\
\text { No. samples }\end{array}$ & $\begin{array}{l}97 \\
116(9-544) \\
9(<5-57) \\
53\end{array}$ & $\begin{array}{l}75(9-956) \\
3(<5-16) \\
29\end{array}$ & $\begin{array}{l}23(<5-59) \\
3(<5-10) \\
6\end{array}$ & $\begin{array}{l}21(<5-40) \\
<5 \\
4\end{array}$ \\
\hline $\begin{array}{l}\text { June } 1997 \\
\text { Respirable dust } \\
\text { Cristobalite } \\
\text { No. samples }\end{array}$ & $\begin{array}{l}183(107-292) \\
16(11-25) \\
3\end{array}$ & $\begin{array}{l}236(55-395) \\
11(<5-23) \\
8\end{array}$ & $\begin{array}{l}78(16-480) \\
<5(<5-58) \\
26\end{array}$ & $\begin{array}{l}45(25-56) \\
<5 \\
12\end{array}$ \\
\hline
\end{tabular}

DoH devised an air quality banding system (alert levels) for Montserrat in October 1997 (table 2).

\section{RESULTS}

\section{Environmental concentrations of volcanic ash}

Concentrations of respirable particles on Montserrat during the course of the eruption have ranged from a few $\mu \mathrm{g} / \mathrm{m}^{3}$ to several $\mathrm{mg} / \mathrm{m}^{3}$. The limited comparison made of $\mathrm{PM}_{10}$ and respirable dust found that for co-located samplers over 24 hour period, the mean concentrations of $\mathrm{PM}_{10}$ and respirable dust were $52 \mu \mathrm{g} / \mathrm{m}^{3}$ and $42.5 \mu \mathrm{g} / \mathrm{m}^{3}$ (mean of four samples) respectively. The cristobalite content of airborne respirable dust in samples collected between September 1996 and June 1997 (table 3) was generally about 10\%, less than in the original ash. ${ }^{1}$ During 1999, however, the cristobalite content of freshly fallen ash rose from about $15-20 \%$ to nearer $30 \%$ (unpublished data from the British Geological Survey).

Airborne dust concentrations have been highest in parts of the island closest to the volcano and during periods of increased volcanic activity and dry weather. Wind direction and strength at different altitudes have been important determinants of how much ash has drifted northwards into occupied parts of the island. The predominant low level wind is from the east and most of the ash has been blown over Plymouth and out over the sea. A substantial amount of ash has however, found its way northwards across the island and affected areas such as Cork Hill and Salem (fig 1). Ambient concentrations of respirable dust and $\mathrm{PM}_{10}$ in Cork Hill prior to evacuation in June 1997 were frequently in the range of $100-500 \mu \mathrm{g} / \mathrm{m}^{3}$ (tables 3 and 4). Concentrations in Salem during the same period were generally lower than in Cork Hill, but subsequently rose during the summer to early autumn of 1997 (tables 3 and $4)$. The high concentrations of airborne particulate added weight to the decision to evacuate Salem, which was considered to be at an unacceptable risk of death and injury from the growing eruptive activity. About a hundred people remained in Salem during the period of official evacuation that lasted until October 1998. These persons would have been exposed to ash from repeated ashfalls, as well as abundant amounts of resuspended ash until activity waned in April 1998.

Concentrations of respirable particulate in ambient air in Salem during 1998 were generally low, with a few dustier days when increased volcanic activity combined with a southerly wind and dry weather led to relatively high dust concentrations (table 5). Official reoccupation of Salem commenced during October 1998. The volcanic activity was much less than

Table 4 Environmental concentrations of $\mathrm{PM}_{10}$ (containing approximately $10 \%$ crystalline silica) in $\mathrm{\mu g} / \mathrm{m}^{3}$ as estimated from DUSTTRAK measurements made between June 1997 and September 1998

\begin{tabular}{llllll}
\hline & \multicolumn{2}{l}{ Little volcanic ash } & & \multicolumn{2}{l}{ High volcanic ash, dry } \\
\cline { 2 - 3 } \cline { 5 - 6 } & Wet & Dry & & Wind not from south & Southerly wind \\
\hline Plymouth & 35 & $150(70-180)$ & & $>1000(1000-2000)$ & Not measured \\
Cork Hill & $30(19-35)$ & $60(35-75)$ & & $1000(1000-3500)$ & Not measured \\
Salem & $20(15-30)$ & $30(25-130)$ & & $200(55-500)$ & $800(100-1000)$ \\
North & $20(15-25)$ & $30(20-60)$ & & $50(45-80)$ & 500 \\
\hline
\end{tabular}

The ranges of measured 15 minute (approximate) means at each location are shown in brackets. High ash days are those in which indoor surfaces are covered with a visible layer of dust. 
Table 5 Environmental concentrations of $\mathrm{PM}_{10}$ measured on Montserrat 1998-99 using DUSTTRAK monitors

\begin{tabular}{|c|c|c|c|}
\hline Location & $\begin{array}{l}\text { Period over which } \\
\text { measurements made }\end{array}$ & $\begin{array}{l}\text { Mean daily mean } \\
\text { concentration of } \mathrm{PM}_{10} \\
\text { (SD), } \mu \mathrm{g} / \mathrm{m}^{3}\end{array}$ & $\begin{array}{l}\text { Percentage of daily } \\
\text { mean measurements } \\
>50 \mu \mathrm{g} / \mathrm{m}^{3}\end{array}$ \\
\hline \multirow[t]{2}{*}{ St Johns - MVO (North) } & 8 March to 30 August 1998 & $19.9(16.5)$ & $5 \%$ \\
\hline & 13 June to 6 August 1999 & $32.8(16.1)$ & $21 \%$ \\
\hline Woodlands & 8 March to 22 August 1998 & $23.6(19.7)$ & $10 \%$ \\
\hline Salem-MVO (South)* & 8 March to 2 July 1998 & $24.2(16.5)$ & $10 \%$ \\
\hline \multirow{2}{*}{ Salem-central square } & 20 May to 30 August 1998 & 39.9 (44.6) & $18 \%$ \\
\hline & 16 May to 6 August 1999 & 80.9 (100.0) & $59 \%$ \\
\hline Iles Bay* & 15 May to 6 August 1999 & $62.1(49.5)$ & $56 \%$ \\
\hline Cork Hill* & 16 May to 6 August 1999 & $56.6(43.6)$ & $52 \%$ \\
\hline
\end{tabular}

St Johns and Woodlands are in the North of the Island and Isles Bay is within the area classified as Cork Hill in other tables.

*Area not occupied during measurement period.

Table 6 Estimated proportion (\%) of days with differing levels of dustiness based on measurement data (tables 3-5), reported levels of volcanic activity (MVO), and information from interviews with islanders

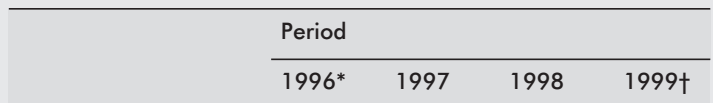

Proportion of days with alert level dust concentrations $\left(>300 \mu \mathrm{g} / \mathrm{m}^{3}\right)$ Cork Hill

Salem

2

10

North

$\begin{array}{ll}1 & 5 \\ 0 & 2\end{array}$

0

0

Proportion of days with very high dust c $\mu \mathrm{g} / \mathrm{m}^{3}$ )

\begin{tabular}{|c|c|c|c|c|}
\hline Cork Hill & 5 & 20 & 1 & 5 \\
\hline Salem & 2 & 5 & 1 & 5 \\
\hline North & 1 & 2 & 1 & 5 \\
\hline Cork Hill & 10 & 50 & 15 & 50 \\
\hline \multicolumn{5}{|c|}{ Proportion of days with raised dust concentrations $\left(50-100 \mu \mathrm{g} / \mathrm{m}^{3}\right)$} \\
\hline Salem & 5 & 30 & 15 & 55 \\
\hline North & 1 & 10 & 5 & 20 \\
\hline
\end{tabular}

Note that Cork Hill has been unoccupied since mid 1997 and Salem was officially unoccupied between August 1997 and October 1998. *April to December.

†January to August-rainfall data used to estimate proportion of days between January and April.

during 1997 and the weather was unusually wet, even during the "dry season". During 1999 the volcano had frequent but light emissions of ash from small venting and explosion events. The ashfalls, mostly light, contributed to maintaining increased ash concentrations in ambient air (table 5). In addition, substantial quantities of unconsolidated ash were washed across road surfaces and were available to become readily airborne as a result of passing traffic. With time, how- ever, an increasing amount of ash has been washed off the island by surface runoff following heavy rain, and the remaining ash in the occupied part of the island has been bound together by grass and other vegetation. Rainfall records showed above average frequent rainfall, even during the dry season, throughout most of 1999 and the early part of 2000. This has probably contributed to the much lower ash concentrations than were recorded during 1997.

Concentrations of respirable particulate in the northern part of the island have generally been low throughout the eruption (tables 3, 4, and 5). Typical concentrations of $\mathrm{PM}_{10}$ have been between 10 and $30 \mu \mathrm{g} / \mathrm{m}^{3}$. Concentrations of $\mathrm{PM}_{10}$ exceeded $300 \mu \mathrm{g} / \mathrm{m}^{3}$ on a few days during 1997 when increased volcanic activity coincided with unfavourable winds, resulting in ash deposits, but these were soon removed by rain. Concentrations were raised on a number of days during 1998 and also during 1999 (tables 5 and 6). A major source of airborne particulate in the north of the island has been from construction work arising from the need to rehouse the island's population in this area. Other sources of non-volcanic particulate include dust raised from the road, smoke from the landfill site, vehicle emissions, and sea spray.

Rainstorms during the autumn of 1999 removed much of the remaining loose ash from occupied areas of the island. The limited information available for the early part of 2000 suggests that individual dust exposures were generally low and ambient air levels were well under the UK air quality standard for $\mathrm{PM}_{10}$.

\section{Personal exposures to volcanic ash}

Table 7 shows the measured levels of personal exposure to respirable dust and cristobalite that islanders were exposed to during 1997. These cyclone measurements and DUSTTRAK measurements of exposure to $\mathrm{PM}_{10}$ showed that personal exposures were heavily influenced by both the activities

Table 7 Mean (range) personal exposures to respirable dust and cristobalite measured using cylcone samplers during June 1997 (average concentrations measured over 4-8 hour shifts)

\begin{tabular}{llll}
\hline & \multicolumn{2}{l}{ Concentration $\left(\mu \mathrm{g} / \mathrm{m}^{3}\right)$} & \\
\cline { 2 - 3 } Occupation & Respirable dust & Cristobalite & Number of samples \\
\hline Gardener/handyman & $825(817-833)$ & $41(<5-82)$ & 2 \\
Roadworkers & $>20000(77-71000)$ & Not measured & 6 \\
Police at road checkpoint & $373(45-778)$ & $51(<5-76)$ & 3 \\
Housekeeper & 442 & 30 & 1 \\
Waiter & 96 & 11 & 1 \\
Office worker & 173 & 18 & 1 \\
Driving & $357(144-830)$ & $32(<5-105)$ & 5 \\
\hline
\end{tabular}


Table 8 Summary of personal exposure concentrations measured in April 2000 using cyclone samplers $\left(\mu \mathrm{g} / \mathrm{m}^{3}\right)$

\begin{tabular}{|c|c|c|c|c|c|}
\hline \multirow[b]{2}{*}{ Description } & \multicolumn{2}{|c|}{ Respirable dust* } & \multicolumn{2}{|c|}{ Cristobalite } & \multirow{2}{*}{$\begin{array}{l}\text { Number of } \\
\text { samples }\end{array}$} \\
\hline & Mean & Range & Mean & Range & \\
\hline Background & 32 & $22-46$ & $<4$ & $<6$ & 4 \\
\hline Gardener & 134 & $7-444$ & $<14$ & $<9-23$ & 6 \\
\hline Hotel housekeeper & 41 & $31-52$ & $<14$ & $<15$ & 3 \\
\hline Housekeeper & 50 & $12-105$ & $<20$ & $<25$ & 9 \\
\hline Housewife & 12 & & $<20$ & & 1 \\
\hline Scientist & 46 & $16-75$ & $<11$ & $<13$ & 2 \\
\hline Maintenance & 11 & $6-81$ & $<19$ & $<20$ & 2 \\
\hline Office & 39 & & $<19$ & & 1 \\
\hline Police & 16 & $4-34$ & $<10$ & $<12$ & 10 \\
\hline Public works & 54 & $33-85$ & $<11$ & $<11$ & 7 \\
\hline Shopworker & 105 & $83-126$ & $<11$ & $<11$ & 2 \\
\hline
\end{tabular}

Most measurements of cristobalite were below the limit of detection.

undertaken by individuals and the general dustiness of the environment. Activities such as cleaning, gardening, or clearing the roads (under dry conditions), actively disturbed deposited dust such that workers created dust clouds around themselves. Concentrations of $\mathrm{PM}_{10}$ associated with mowing grass outside and sweeping inside, for example, were of the order of $10-20 \mathrm{mg} / \mathrm{m}^{3} \quad\left(10000-20000 \mathrm{\mu g} / \mathrm{m}^{3}\right)$. Vehicles travelling across dry, ash covered roads raised tremendous dust clouds, even when there was only a light dusting of ash on the road surface. Road surfaces also dried out very rapidly in comparison to vegetated areas following any rainfall. Driving and any activity undertaken immediately adjacent to the roadside, such as manning checkpoints, was associated with relatively high levels of exposure to the ash. Concentrations of $\mathrm{PM}_{10}$ within vehicles were of the order of $100-1000 \mu \mathrm{g} / \mathrm{m}^{3}$ throughout any journey, and peaks of concentration both within vehicles and at the roadside exceeded $5000 \mu \mathrm{g} / \mathrm{m}^{3}$. Outdoor levels of exposure to volcanic ash were very dependent on the dampness of the weather. Disturbance of wet ash had very little effect on airborne dust concentrations.

Subsequent measurements made during 1998 confirmed that those in the dustiest occupations-housekeepers, gardeners, handymen, and roadworkers-continued to have some high exposures to volcanic ash. For those in outdoor occupations, high exposures were most likely on dry days when the combination of volcanic activity and weather had led to the recent deposition of volcanic ash within the working environment. Housekeepers were repeatedly exposed to high concentrations of ash indoors because it was impossible to keep indoor surfaces completely free of ash, and the main methods of cleaning used were sweeping and dusting. Outdoor exposures to airborne dust during wet weather were
Table 9 Estimated mean personal exposure of children in school to $\mathrm{PM}_{10}$

\begin{tabular}{lcc}
\hline & $\begin{array}{c}\text { Personal } \\
\text { exposure } \\
\text { to PM }\end{array}$ & $\begin{array}{l}\text { Background } \\
\text { concentration } \\
\text { of } \text { PM }_{10}\end{array}$ \\
\cline { 2 - 3 } Activity & $\left(\mu \mathrm{g} / \mathrm{m}^{3}\right)$ & $\left(\mu \mathrm{g} / \mathrm{m}^{3}\right)$ \\
\hline Sitting in class (mean) & 98 & 14 \\
Sweeping & 272 & 8 \\
Games, rounders, other outdoor play (mean) & 144 & 13 \\
Break, lunchtime (inactive) (mean) & 88 & 15 \\
Packing up (mean) & 155 & 13 \\
\hline Results based on 9 days of measurement during March and April \\
1998 using a DUSTTRAK monitor.
\end{tabular}

very low, and the general prevalence of wet weather during 1998 (MVO records) and 1999 (Forestry Development records) suggest that dust exposures for those in outdoor occupations have been relatively low on a substantial proportion of days.

Measurements made during April 2000 suggested that levels of exposure continued to be very low (table 8 ). Only one sample contained a measurable amount of cristobalite.

The importance of both weather (especially rainfall) and activity in controlling individual exposure to airborne particles was particularly well shown by a study of the exposure of schoolchildren to $\mathrm{PM}_{10}$ during the early months of 1998. This survey was undertaken in response to local concerns about the potential effects of exposure to volcanic ash on children's health. By this time, the amount of ash in the environment had been reduced in comparison to the levels prevalent in 1997, but many outdoor surfaces were still partly covered by some ash. The weather at the time of the survey was damp. The results show that children's exposure to ash was greatly affected by their activities, with exposures being least during periods of relative inactivity (table 9). The overall exposure of children to airborne particulate over 24 hours was estimated to be less than $70 \mu \mathrm{g} / \mathrm{m}^{3}$. Levels of exposure to airborne ash are, however, likely to have been much higher for children resident in Cork Hill or Salem prior to evacuation of these areas.

\section{Estimated exposures to cristobalite during the course of the volcanic eruption}

Mean personal exposures to volcanic ash containing cristobalite were estimated for different groups of islanders in order to allow an assessment of the potential silicosis risk. This involved making assumptions based on interview evidence and direct observation about the lifestyle of people on the island (table 10). The grouping of islanders into different groups was based on measurement data showing that personal exposures were greatest for those living closest to the volcano and in dusty occupations. The measurement data also

Table 10 Assumed lifestyle of different population groups

\begin{tabular}{|c|c|c|c|c|c|}
\hline & Inactive & $\begin{array}{l}\text { Active } \\
\text { indoors* }\end{array}$ & $\begin{array}{l}\text { Active } \\
\text { outside }\end{array}$ & Outdoor play & Dusty occupations $†$ \\
\hline Example activities & $\begin{array}{l}\text { Sleeping } \\
\text { Watching TV }\end{array}$ & $\begin{array}{l}\text { Housework } \\
\text { Catering } \\
\text { Retail }\end{array}$ & $\begin{array}{l}\text { Walking } \\
\text { Driving }\end{array}$ & Basketball & $\begin{array}{l}\text { Gardening } \\
\text { Cleaning } \\
\text { Roadworkers }\end{array}$ \\
\hline Sedentary adults & 23 & 1 & & & \\
\hline Active adults & 13 & 9 & 2 & & \\
\hline $\begin{array}{l}\text { Adults with dusty } \\
\text { jobs* }\end{array}$ & 13 & 4 & 2 & & $5 \ddagger$ \\
\hline Children & 14 & 7 & 1 & 2 & \\
\hline
\end{tabular}

Results expressed as hours spent each day on different activities.

*Includes professional indoor cleaning.

†Includes those employed in Plymouth until June 1997.

$\ddagger$ Assumes an 8 hour shift on working days. 
Table 11 Estimated mean personal exposure concentrations associated with different groups of activity on days of differing background dustiness $\left(\mu \mathrm{g} / \mathrm{m}^{3}\right)$

\begin{tabular}{lccccc}
\hline $\begin{array}{l}\text { Exposure to } \mathrm{PM}_{10} \text { on } \\
\text { days of differing dustiness }\end{array}$ & Inactive & $\begin{array}{l}\text { Active } \\
\text { indoors }\end{array}$ & $\begin{array}{l}\text { Active } \\
\text { outside }\end{array}$ & $\begin{array}{l}\text { Outdoor } \\
\text { play }\end{array}$ & $\begin{array}{l}\text { Dusty } \\
\text { occupations }\end{array}$ \\
\hline $\begin{array}{l}\text { Alert level } \\
\text { Very high ash }\end{array}$ & 1000 & 2000 & 3000 & 10000 & 10000 \\
"Raised" ash & 300 & 500 & 1000 & 5000 & 5000 \\
Low ash & 100 & 150 & 200 & 500 & 500 \\
\hline
\end{tabular}

Table 12 Approximate mean personal exposure concentrations $\left(\mu \mathrm{g} / \mathrm{m}^{3}\right)$ of respirable dust and cristobalite lassuming a mean cristobalite content of $15 \%$ in airborne dust) during the course of the current eruption (April 1996 to August 1999)

\begin{tabular}{|c|c|c|c|c|c|c|}
\hline & \multicolumn{3}{|c|}{ Respirable dust } & \multicolumn{3}{|c|}{ Cristobalite } \\
\hline & Cork Hill* & Salem† & North & Cork Hill & Salem & North \\
\hline Sedentary adults & 100 & 60 & 40 & 15 & 10 & 5 \\
\hline Active adults & 140 & 90 & 60 & 20 & 20 & 10 \\
\hline Adults with dusty occupations & 390 & 260 & 180 & 60 & 40 & 30 \\
\hline Children & 200 & 130 & 80 & 30 & 20 & 10 \\
\hline
\end{tabular}

The US (ACGIH) limit for workplace exposure to cristobalite adjusted for 24 hour exposure over 365 days/year is equivalent to $10 \mu \mathrm{gg} / \mathrm{m}^{3}$.

*Assumes evacuation to Salem in June 1997 and then to north of island in August 1997.

†Asumes evacuated to north of island between August 1997 and October 1998.

indicated that children were potentially exposed to high levels of volcanic ash because they were playing on ash covered playgrounds and actively playing with the ash. There is considerable uncertainty in the estimates of the proportion of time spent on activities of different dustiness as individuals had very different daily routines and would also do different things on different days. For example, some of those in dusty jobs would have been working 10 hour shifts or on six rather than five days a week, while others were only effectively working five hour shifts, after meal breaks and travelling time, on less than five days a week.

The measurement data were used to estimate mean exposures to airborne dust associated with different categories of activities on days of different dustiness (table 11). Given the limited measurement data, these estimates incorporate a substantial amount of professional judgement.

The estimated exposure associated with each activity, the proportion of time spent in each activity, and the proportion of days with differing levels of dustiness were combined to give an estimated mean level of exposure for each group of islanders since April 1996 (table 12). Given the uncertainties involved in these estimates and the likely variation of exposure within each exposure group, it is possible that the most exposed members in each group have been exposed to exposure concentrations that are up to twice those shown. There will also be individuals who will have much lower exposures, particularly among the active adults, adults in dusty occupations, and children. Some individuals in these groups will have had exposures more similar to those estimated for the sedentary adults. The estimates in table 12 do, however, suggest that levels of exposure to cristobalite during the early years of the eruption were relatively high in comparison to the ACGIH TLV. The groups with the highest exposure were those originally resident in Cork Hill and those in dusty occupations.

\section{DISCUSSION}

\section{Exposure to volcanic ash on Montserrat}

The concentrations of fine particles measured as $\mathrm{PM}_{10}$ on Montserrat have been high compared with typical rural or urban concentrations in the UK. Annual mean concentrations of $\mathrm{PM}_{10}$ in central London, for example, are about $25 \mu \mathrm{g} / \mathrm{m}^{3}$, and concentrations in other UK cities are somewhat lower. ${ }^{4}$ The long period over which concentrations of such fine airborne dust have been increased on Montserrat is quite unusual, even for dust associated with a volcanic eruption. Patterns of environmental exposure to airborne dust in the UK include some short term peaks in concentration (daily mean concentration greater than $50 \mu \mathrm{g} / \mathrm{m}^{3}$ gravimetric equivalent) on about 10 days in a year in most urban areas, and over 50 days in a year in a few locations (for example, Port Talbot).$^{10}$ Most volcanic dusts are coarser than that on Montserrat and therefore less of a respiratory hazard, and many eruptions are relatively short lived compared with the activity on Montserrat.

Estimation of parameters used in exposure estimation A number of assumptions and simplifications had to be made in order to calculate cumulative exposures for different population groups. The most important effect of these simplifications is that the risks may have been underestimated for a few individuals with particularly dusty lifestyles. For example, the short shift length assumed for those in dusty occupations could lead to an underestimation of the exposure of those who effectively hold several jobs. Thus some individuals will work long hours looking after a number of gardens and undertaking maintenance tasks on ash covered buildings. The risks may be overestimated for some other individuals, such as office workers occupying a quiet office on their own, who would have much lower exposure than would be typical of other indoor workers.

\section{Silicosis risk}

There are considerable uncertainties associated with the assessment of risk of silicosis. The dose-response information available for crystalline silica is for quartz rather than cristobalite. Cristobalite is generally considered to be more toxic than quartz and cell tests suggest that the ash is as toxic as quartz in some assays. ${ }^{11}$ Very discordant relations between exposure (normally assessed in terms of cumulative exposure) and response have been found in different epidemiological studies (fig 2). ${ }^{12}$ Some of these anomalies may reflect differences in the biological activity of quartz from different environments with factors such as particle size, surface area, and particle surface properties all being important. Other differences may arise 


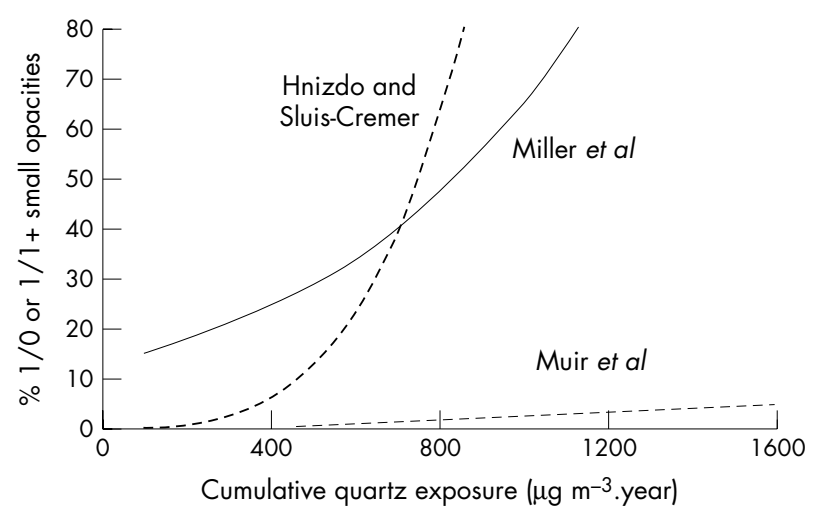

Figure 2 Risks of silicosis associated with exposure to crystalline silica (as quartz) found in different workplace studies. Exposure axis rescaled for environmental exposure (environmental exposure to 100 $\mathrm{ug} \mathrm{m}^{-3}$ for one year is equivalent to a workplace exposure of 500 $\mu \mathrm{g} \mathrm{m}^{-3}$ over one year).

from the relatively poor characterisation of exposure in some studies. There is limited evidence that a short term exposure to a very high concentration of crystalline silica may be more damaging than the same cumulative exposure in terms of concentration.time but over a much longer time period (compare Miller and colleagues ${ }^{13}$ and Hnzido and Sluis-Cremer, ${ }^{14}$ where exposure was to very high concentrations of silica, to Muir and colleagues, ${ }^{15}$ where exposure was to much lower concentrations). The average levels of exposure to cristobalite for most of the general population on the island, however, have been very low in comparison with workplace exposure, even after allowing for the difference in duration of exposure.

In view of the uncertainties described above, the view was taken to follow the ACGIH occupational exposure limit as a suitable reference point for defining silicosis risk. The ACGIIH have recommended that workplace exposure to cristobalite in the USA is controlled to $50 \mu \mathrm{g} / \mathrm{m}^{3}$. The ACGIH committee believed that the development of silicosis was not likely to be associated with this level of exposure to cristobalite over a 40 year working lifetime. The cumulative exposure arising from one year of continuous exposure to a given concentration of silica is approximately five times greater than if exposure is confined to a 40 hour working week on 46 weeks of the year. This suggests that long term (that is, over 20-40 years) mean personal exposures to cristobalite on Montserrat should be controlled to less than $10 \mu \mathrm{g} / \mathrm{m}^{3}$ to adequately protect against silicosis. The mean exposure of some groups currently exceeds 10 $\mu \mathrm{g} / \mathrm{m}^{3}$, but this is a result of very high levels of exposure during the first six to eight months of 1997. Provided that future volcanic activity does not deposit large quantities of ash in the occupied areas of the island and islanders use appropriate respiratory protection and working methods to minimise future occupational exposure to ash, the long term mean exposure of most of the population should be close to or below $10 \mu \mathrm{g} / \mathrm{m}^{3}$. There may be a few individuals who have already had sufficient exposure to cristobalite to be at risk of developing mild silicosis at a level unlikely to give rise to clinical symptoms. The individuals at most risk are those who have been occupationally exposed to high dust concentrations or have spent substantial amounts of time clearing ash from properties in the areas most affected by the ash. A few of these individuals may be at risk of developing more severe silicosis leading to impairment of lung capacity and breathlessness, particularly if they have continued to have relatively high levels of occupational exposure to the ash. If the eruption were to continue until 2005 (that is, have a total duration of 10 years which is not untypical for this type of volcano), then more of those in dusty occupations could be at risk of developing silicosis, with a few possibly developing respiratory symptoms. A chest $x$ ray survey has been under- taken in late 2000 to identify any individuals with early silicosis. Seaton and Cherrie have suggested that hilar enlargement with minimal lung involvement may be an early radiological manifestation of silicotic disease. ${ }^{16}$

The silicosis risk associated with exposure to volcanic ash was previously studied following the 1980 eruption of Mount St Helens, USA, when three ashfalls occurred in areas of central and eastern Washington and affecting Portland, Oregon. The ash contained 7\% quartz, 3\% cristobalite, and a small amount of tridymite. The ash was found to be considerably less toxic in vitro than quartz. ${ }^{17}$ Two long term animal studies did, however, show that the ash caused some lung pathological changes at high exposure concentrations. ${ }^{18}{ }^{19}$ Concerns over the health risk were not the same as on Montserrat because of the short duration of the eruption. The toxic potential of the Montserrat ash would be expected to be greater than that of Mount St Helens ash because of its much higher cristobalite content.

\section{Other chronic health effects}

The increased risks of developing chronic respiratory illnesses, such as bronchitis, through exposure to volcanic ash on Montserrat are less quantifiable. There is increasing evidence that chronic exposure to fine particulate in urban environments does slightly increase an individual's risks of developing chronic bronchitis. ${ }^{20}$ Ash may act as a non-specific irritant on the airways, leading to an increase in the amount of mucous produced by the mucous glands, and perhaps to inflammation. It is conceivable that long term exposure to volcanic ash, like other occupational dusts, can lead to chronic bronchitis. Human studies after the Mount St Helens eruption were not able to determine whether acute and/or chronic exposure to inhaled ash affects the reactivity of the airways, which could be a factor in the long term development of chronic obstructive pulmonary disease. ${ }^{21}$

\section{Risk of acute respiratory effects}

Dose-response relations describing the association between exposure to $\mathrm{PM}_{10}$ in urban areas and health effects were reviewed by the Expert Panel on Air Quality Standards. ${ }^{8}$ These relations predict that the prevalence of symptoms in individuals with asthma could be doubled during periods of increased dust concentrations on Montserrat. The nature of airborne particulate on Montserrat is, however, very different from that in the urban areas where effects have been observed, so that the actual scale of any effect is difficult to predict. Concentrations of $\mathrm{PM}_{10}$ measured on Montserrat during the eruption have, however, been sufficiently increased to expect some exacerbation of asthmatic symptoms.

A survey of schoolchildren on the island, carried out in February 1998, showed a higher prevalence of wheeze symptoms in children who had lived in areas most affected by ash in the preceding year. ${ }^{22}$ The prevalence of symptoms of wheeze in the previous year was $18 \%$ (children aged 12 years and under) and 16\% (children aged 13 years and over). The results may have been biased by the selective evacuation of known susceptible individuals, such as asthma sufferers, from the island. Other susceptible individuals may not, however, have had a previous record of respiratory ill health. Many islanders have complained of eye and throat irritation caused by the ash, which might also have been aggravated by the surface acidity of freshly erupted particles.

\section{Measures to reduce personal exposures}

Since the initial concern in the autumn of 1996 about the potential health effects associated with exposure to the volcanic ash, public information has been provided on methods of minimising exposure. Advice has been given to the whole population on reducing exposure in the expectation that lowering the overall average exposure will also reduce the high exposures of the minority most exposed through their work or outdoor activities. The success of clean up after ash 
falls requires the involvement of the whole community, for example, and not just dedicated groups of workers. However, we have clearly defined in our survey groups of outdoor workers, such as gardeners, who are most at risk of developing silicosis, and these should be specially targeted for preventive measures. Appropriate disposable respiratory protection has been provided for the general public and workers since 1997. There have been a number of limitations on the use of respiratory protection, including the lack of commercially available dust masks that would fit young children. The warm climate makes the wearing of masks extremely uncomfortable and many workers exposed to the ash may not have routinely used the respiratory protection that was available. In September 1998 the authorities issued a leaflet on the ash and protective measures to be used, such as dampening down, when cleaning up houses in Salem before they were reoccupied. School play areas were hosed down to remove ash that could be made airborne by the children's activities. Guidelines were also issued on the criteria for reoccupation of rehabilitated areas.

There is little information available on the extent to which the population and workers adhered to the advice on personal protection measures, including the wearing of masks when exposed to high levels of ash in the air. In consequence we did not include an exposure reduction factor in our exposure estimates.

\section{CONCLUSIONS}

During the course of the eruption the population of Montserrat has been exposed to increased airborne concentrations of airborne particles (including respirable dust and $\mathrm{PM}_{10}$ ) which has contained a significant component of crystalline silica in the form of the toxic mineral cristobalite.

Concentrations of volcanic ash have been highest in western and central southern parts of the island closest to the volcano, during periods of increased volcanic activity and during dry weather. The overall exposure of islanders to volcanic ash has been in effect limited because of the relocation of the population to the north of the island in response to the threat to life from the volcano. This part of the island is only rarely downwind of the volcano and airborne particle concentrations are probably similar to those on any other Caribbean island.

The islanders with the highest exposures to volcanic ash are those in occupations including cleaning, gardening, handymen, roadworkers, and those undertaking a lot of driving or manning roadside checkpoints. A few of these individuals may have had sufficient exposure to crystalline silica to have a small long term risk of developing silicosis.

The increased concentrations of particles on the island are likely to have caused some acute exacerbation of symptoms in those with pre-existing respiratory conditions.

Recent studies have shown that cristobalite concentrations in the abundant ash deposits around the flanks of the volcano are in the range of 15-25 weight \%, and the majority of the particles are $\mathrm{PM}_{10}$ regardless of weathering processes. Respiratory health considerations are likely to dominate decision making on the reoccupation of areas south of the Belham River, including the devastated capital Plymouth. This assessment shows the need to continue individual and ambient air monitoring and to limit exposure to occupational exposure limits for crystalline silica and their environment equivalent values. Exposures to fine ash particles could continue from intermittent, moderate eruptive activity for years to come, as well as the resuspension of ash from ground deposits until they become safely sequestered by a layer of topsoil and vegetation.

\section{ACKNOWLEDGEMENTS}

Daily air quality measurements were made on Montserrat between August 1997 and August 1998 by Costanza Bonadona, Graham Ryan, Haley Duffel, Kathryn Moore, Colin Walker, and Sarah Dornan. Kathyrn Moore also undertook some surveys of personal exposure, including the study of schoolchildren. Air quality measurements between May 1999 and August 1999 were made by Claire Horwell and Pyiko Williams. This work has been funded by the Department for International Development (DFID) and we thank the DFID Office on Montserrat for providing us with logistic support during our visits to the island. We thank the many individuals on the island who have worn personal sampling equipment, enabling the measurement of personal exposure concentrations. We also thank the staff at MVO for their support, in particular Dr S Young. Mr T Hill of the Montserrat Forestry Development Office kindly provided rainfall data. Prof A Seaton and Dr RL Maynard gave us invaluable advice on health aspects throughout this work, and Prof. RS Sparks provided technical guidance on volcanological issues. The ash was also analysed by the British Geological Survey and we thank R Nicholson and V Hards for their assistance.

...................

Authors' affiliations

A Searl, A Nicholl, Institute of Occupational Medicine, 8 Roxburgh Place, Edinburgh EH8 9SU, UK

P J Baxter, Department of Public Health and Primary Care, Institute of Public Health, University of Cambridge, Robinson Way, Cambridge

CB2 2SR, UK

\section{REFERENCES}

1 Baxter PJ, Bonadonna C, Dupree R, et al. Cristobalite in volcanic ash of the Soufriere Hills Volcano, Montserrat, British West Indies. Science 1999;283: 1142-5

2 International Agency for Research on Cancer. Silica, some silicates, coal dust and para-aramid fibrils. IARC Monographs on the Evaluation of Carcinogenic Risks to Humans, Volume 66. Lyon, 1997.

3 Hemenway DR, Absher MP, Trombey L, et al. Comparative clearance of quartz and cristobalite from the lung. Am Ind Hyg Assoc J 1990;51:363-9.

4 Quality of Urban Air Review Group. Airborne particulate matter in the United Kingdom, 3rd report. London: Department of the Environment, 1996.

5 Health and Safety Executive. General methods for the gravimetric determination of respirable and total inhalable dust. Methods for the Determination of Hazardous Substances 1997:14/2.

6 Health and Safety Executive. Cristobalite in respirable airborne dusts. Methods for the Determination of Hazardous Substances 1994:76

7 American Conference of Government Industrial Hygienists. TLVs and other occupational exposure values. Cincinnati, 1998 (CD-ROM, includes criteria documents).

8 Expert Panel on Air Quality Standards. Particles. London: HMSO, Department of the Environment, 1998

9 Health and Safety Executive. Occupational exposure limits 1998. Environmental Health Series 40/98.

10 Department for Environment. Food and Rural Affairs. The air quality strategy for England, Scotland, Wales and Northern Ireland. A consultation document on proposals for air quality objectives for particles, benzene, carbon monoxide and polycyclic aromatic hydrocarbons. 2001.

11 Wilson MR, Stone V, Cullen RT, et al. In vitro toxicology of respirable Montserrat volcanic ash. Occup Environ Med 2000;57:727-33.

12 Pilkington A, Maclaren W, Searl A, et al. Scientific opinion on the health effects of airborne crystalline silica. Edinburgh: IOM Technical Memorandum, 1996 (TM/95/08).

13 Miller BG, Hagan S, Love RG, et al. Risks of silicosis in coalworkers exposed to unusual concentrations of respirable quartz. Occup Environ Med 1998;55:52-8.

14 Hnizdo E, Sluis-Cremer GK. Silica exposure, silicosis and lung cancer: a mortality study of South African gold miners. $\mathrm{Br} J$ Ind Med 1991:48:53-60.

15 Muir DCF, Julian JA, Shannon HS, et al. Silica exposure and silicosis among Ontario hardrock miners: III. Analysis and risk estimates. Am J Ind Med 1989;16:29-43

16 Seaton A, Cherrie JW. Quartz exposures and severe silicosis: a role for the hilar nodes. Occup Environ Med 1998;55:583-6.

17 Martin TR, Wehner AP, Butler J. Evaluation of physical health effects due to volcanic hazards. The use of experimental systems to estimate the pulmonary toxicity of volcanic ash. Am J Public Health 1986;76:59-65.

18 Sanders CL, Rhoads K, Mahaffey JA. Long term reactivity of lung and mediastinal lymph nodes following intratracheal instillation of sandy loan soil or Mount St Helens volcanic ash. Environ Res 1983;27: 1 18-35.

19 Wehner AP, Dagle GE, Clark ML, et al. Lung changes in rats inhaling volcanic ash for one year. Am Rev Respir Dis 1983;128:926-32.

20 Pope A, Dockery D. Epidemiology of chronic health effects: cross sectional studies. In: Wilson R, Spengler J, eds. Particles in our air Harvard: Harvard University Press, 1996:149-68.

21 Buist AS, Bernstein RS, Johnson LR, et al. Evaluation of physical health effects due to volcanic hazards: human studies. Am J Public Health 1986;76(suppl):66-75

22 Forbes L, Jarvis D, Potts J, et al. Volcanic ash and respiratory symptoms in children on the island of Montserrat, British West Indies. In preparation. 